\title{
PENINGKATAN KOMPETENSI GURU DALAM MENYUSUN SILABUS DAN RPP MELALUI BIMBINGAN BERKELANJUTAN DI SD NEGERI 145 PALEMBANG
}

\author{
Faizal \\ Guru SD Negeri 145 Palembang \\ faizal@gmail.com
}

\begin{abstract}
Abstrak
Penelitian ini bertujuan untuk mengembangkan teori-teori dalam dunia pendidikan guna menemukan metode yang tepat untuk meningkatkan kemampuan guru dalam menyusun Silabus dan RPP. Subjek penelitian sebanyak 8 orang guru dan dilaksanakan melalui tahap perencanaan, tindakan, observasi/evaluasi dan refleksi. Mula-mula peneliti menyampaikan panduan bagaimana cara menyusun Silabus dan Rencana Pelaksanaan Pembelajran (RPP) kepada guru-guru, kemudian meningkatkan keterampilan guru-guru dalam menyusun Silabus dan Rencana Pelaksanaan Pembelajran (RPP) berbasis Kurikulum 2013 melalui bimbingan berkelanjutan, pada pada siklus I rata-rata hasil aktivitas dan kompetensi guru dalam menyusun silabus dan RPP adalah 75,91 dan pada siklus II rata-rata hasil aktivitas dan kompetensi guru dalam menyusun silabus dan RPP mengalami peningkatan yakni sebesar 85,35 . Hal ini berarti penelitian telah berhasil dimana apabila silabus dan RPP yang disusun oleh guru kelas dan guru mata pelajaran minimal mencapai nilai kualitatif B (Baik).
\end{abstract}

Kata kunci : Kurikulum 2013, Kompetensi, RPP

\begin{abstract}
This study aims to develop theories in the world of education in order to find the right method to improve the ability of teachers in compiling syllabus and lesson plans. The research subjects were 8 teachers and carried out through the stages of planning, action, observation/evaluation and reflection. At first the researchers conveyed a guide on how to prepare the Syllabus and Learning Implementation Plan (RPP) to teachers, then improve the skills of the teachers in preparing the Syllabus and Learning Implementation Plan (RPP) based on the 2013 Curriculum through continuous guidance, in the first cycle on average. The average result of teacher activity and competence in compiling the syllabus and lesson plans was 75.91 and in cycle II the average result of teacher activity and competence in compiling the syllabus and lesson plans increased by 85.35. This means that the research has been successful where if the syllabus and lesson plans prepared by class teachers and subject teachers at least achieve a qualitative value of $B$ (Good).
\end{abstract}

Keywords: 2013 Curriculum, Competence, RPP 


\section{PENDAHULUAN}

Peraturan Pemerintah Nomor 19 Tahun 2005 tentang 8 Standar Nasional Pendidikan menyatakan standar proses merupakan salah satu SNP untuk satuan pendidikan dasar dan menengah yang mencakup: 1) Perencanaan proses pembelajaran, 2) Pelaksanaan proses pembelajaran, 3) Penilaian hasil pembelajaran, 4) dan pengawasan proses pembelajaran. Perencanaan pembelajaran meliputi Silabus dan Rencana Pelaksanaan Pembelajaran (RPP).

Silabus dan RPP dikembangkan oleh guru pada satuan pendidikan. Guru pada satuan pendidikan berkewajiban menyusun Silabus dan RPP secara lengkap dan sistematis agar pembelajaran berlangsung secara interaktif, inspiratif, menyenangkan, menantang, memotivasi peserta didik untuk berpartisipasi aktif, serta memberikan ruang yang cukup bagi prakarsa, kreativitas,dan kemandirian sesuai dengan bakat, minat dan perkembangan fisik serta psikologis peserta didik.

Masalah yang terjadi di lapangan masih ditemukan adanya guru (baik di sekolah negeri maupun swasta) yang tidak bisa memperlihatkan RPP yang dibuat dengan alasan ketinggalan di rumah dan bagi guru yang sudah membuat RPP masih ditemukan adanya guru yang belum melengkapi komponen tujuan pembelajaran dan penilaian (soal, skor dan kunci jawaban), serta langkah-langkah kegiatan pembelajarannya masih dangkal. Soal, skor, dan kunci jawaban merupakan satu kesatuan yang tidak dapat dipisahkan. Pada komponen penilaian (penskoran dan kunci jawaban) sebagian besar guru tidak lengkap membuatnya dengan alasan sudah tahu dan ada di kepala. Sedangkan pada komponen tujuan pembelajaran, materi ajar, metode pembelajaran, dan sumber belajar sebagian besar guru sudah membuatnya. Masalah yang lain yaitu sebagian besar guru khususnya di sekolah swasta belum mendapatkan pelatihan pengembangan RPP. Selama ini guru-guru yang mengajar di sekolah swasta sedikit/jarang mendapatkan kesempatan untuk mengikuti berbagai Diklat Peningkatan Profesionalisme Guru dibandingkan sekolah negeri. Hal ini menyebabkan banyak guru yang belum tahu dan memahami penyusunan/pembuatan RPP secara baik/lengkap. Beberapa guru 
mengadopsi RPP orang lain. Hal ini peneliti ketahui pada saat mengadakan supervisi akademik (supervisi kunjungan kelas) ke sekolah binaan. Permasalahan tersebut berpengaruh besar terhadap pelaksanaan proses pembelajaran. Rencana Pelaksanaan Pembelajaran harus dibuat agar kegiatan pembelajaran berjalan sistematis dan mencapai tujuan pembelajaran. Tanpa Rencana Pelaksanaan Pembelajaran, biasanya pembelajaran menjadi tidak terarah. Oleh karena itu, guru harus mampu menyusun RPP dengan lengkap berdasarkan silabus yang disusunnya. Rencana Pelaksanaan Pembelajaran sangat penting bagi seorang guru karena merupakan acuan dalam melaksanakan proses pembelajaran.

.Berdasarkan latar belakang di atas, maka masalah-masalah yang muncul dapat diidentifikasikan sebagai berikut : Guru banyak yang belum paham dan termotivasi dalam menyusun Rencana Pelaksanaan Pembelajaran dengan lengkap. Sebagian besar guru belum mendapatkan pelatihan pengembangan Kurikulum 2013. Ada guru yang tidak bisa memperlihatkan RPP yang dibuatnya dengan berbagai alasan. RPP yang dibuat guru komponennya belum lengkap/tajam khususnya pada komponen langkah-langkah pembelajaran dan penilaian. Dari masalah yang diidentifikasikan di atas, masalahnya dibatasi adalah guru belum paham dalam menyusun Silabus dan RPP.Silabus dan RPP yang dibuat guru belum lengkap.

Berdasarkan latar belakang, identifikasi, dan pembatasan masalah di atas, maka rumusan masalah dalam penelitian ini "bagaimanakah peningkatan kompetensi guru dalam menyusun Silabus dan RPP melalui bimbingan berkelanjutan?

Penelitian ini bertujuan untuk mengembangkan teori-teori dalam dunia pendidikan guna menemukan metode yang tepat untuk meningkatkan kemampuan guru dalam menyusun Silabus dan RPP.

$$
\text { Poerwadarminta (dalam }
$$

Suparlan 2005:13) menyatakan, "guru adalah orang yang kerjanya mengajar." Dengan definisi ini, guru disamakan dengan pengajar. Pengertian guru ini hanya menyebutkan satu sisi yaitu sebagai pengajar, tidak termasuk pengertian guru sebagai pendidik dan pelatih. Selanjutnya Zakiyah Daradjat (dalam Suparlan 2005:13) 
menyatakan," guru adalah pendidik profesional karena guru telah menerima dan memikul beban dari orang tua untuk ikut mendidik anakanak."

Depdiknas (2004:4) kompetensi diartikan, "sebagai pengetahuan, keterampilan, dan nilai-nilai dasar yang direfleksikan dalam kebiasaan berpikir dan bertindak". "Secara sederhana kompetensi diartikan seperangkat kemampuan yang meliputi pengetahuan, sikap, nilai dan keterampilan yang harus dikuasai dan dimiliki seseorang dalam rangka melaksanakan tugas pokok, fungsi dan tanggung jawab pekerjaan dan/atau jabatan yang disandangnya" (Sudjana 2009:1).

Nurhadi (2004:15) menyatakan, "kompetensi merupakan pengetahuan, keterampilan, dan nilai-nilai dasar yang direfleksikan dalam kebiasaan berpikir dan bertindak". Selanjutnya menurut para ahli pendidikan McAshan (dalam Nurhadi 2004:16) menyatakan, "kompetensi diartikan Sebagai pengetahuan, keterampilan, dan kemampuan yang dikuasai seseorang sebagai pengetahuan,keterampilan, dan kemampuan yang dikuasai seseorang yang telah menjadi bagian dari dirinya, sehingga dapat melakukan perilakuperilaku kognitif, afektif, dan psikomotor dengan sebaik-baiknya."

Kompetensi diartikan sebagai pengetahuan, keterampilan, dan nilainilai dasar yang direfleksikan dalam kebiasaan berfikir dan bertindak. Arti lain dari kompetensi adalah spesifikasi dari pengetahuan, keterampilan, dan sikap yang dimiliki seseorang serta penerapannya di dalam pekerjaan, sesuai dengan standar kinerja yang dibutuhkan oleh lapangan.

Depdiknas (2004:4) tujuan adanya Standar Kompetensi Guru adalah sebagai jaminan dikuasainya tingkat kompetensi minimal oleh guru sehingga yang bersangkutan dapat melakukan tugasnya secara profesional, dapat dibina secara efektif dan efisien serta dapat melayani pihak yang berkepentingan terhadap proses pembelajaran, dengan sebaik-baiknya sesuai bidang tugasnya. Adapun manfaat disusunnya standar kompetensi guru adalah sebagai acuan pelaksanaan uji kompetensi, penyelenggaraan diklat, dan pembinaan, maupun acuan bagi pihak yang berkepentingan terhadap kompetensi guru untuk melakukan evaluasi, pengembangan bahan ajar 
dan sebagainya bagi tenaga kependidikan.

Kurikulum 2013 merupakan kurikulum tebaru yang diterapkan dalam kegiatan belajar mengajar di negara kita dewasa ini. Kurikulum 2013 bertujuan memberikan ilmu pengetahuan secara utuh kepada siswa dan tidak terpecah-pecah. Kurikulum ini menekankan pada keaktifan siswa untuk menemukan konsep pelajaran dengan guru berperan sebagai fasilitator.

Alasan yang mendasari pemerintah mengembangkan dan melaksanakan kurikulum terbaru ini adalah untuk menghadapi persaingan global yang semakin maju. Pendidikan di Indonesia dinilai cukup terbelakang dibandingkan dengan negara lain. Peringkat pendidikan di Indonesia berada di bawah Thailand dan Malaysia untuk di ASEAN saja (Kemdikbud 2011). Menghadapi perkembangan globalisasi yang semakin membumi, pemerintah mengembangkan kurikulum baru dengan tujuan untuk memperbaiki kualitas pendidikan di Indonesia dan menciptakan kualitas penerus bangsa yang bermutu.
Perencanaan

proses

pembelajaran meliputi silabus dan RPP. Silabus merupakan sebagian subsistem pembelajaran yang terdiri dari atau yang satu sama yang lain saling berhubungan dalam rangka mencapai tujuan. Hal penting yang berkaitan dengan pembelajaran adalah penjabaran tujuan yang disusun berdasarkan indikator yang ditetapkan.

$$
\text { Selanjutnya Oemar Hakim }
$$

(dalam Kurniawati 2009:74) menyatakan, "bahwa perencanaan program pembelajaran pada hakekatnya merupakan perencanaan program jangka pendek untuk memperkirakan suatu proyeksi tentang sesuatu yang akan dilakukan dalam kegiatan pembelajaran".

\section{METODE}

Metode yang digunakan dalam penelitian ini adalah metode Penelitian Tindakan Sekolah (PTS). Penelitian tindakan sekolah merupakan “(1) penelitian partisipatoris yang menekankan pada tindakan dan refleksi berdasarkan pertimbangan rasional dan logis untuk melakukan perbaikan terhadap suatu kondisi nyata; (2) memperdalam pemahaman terhadap tindakan yang dilakukan; dan (3) memperbaiki situasi dan kondisi 
sekolah / pembelajaran secara praktis" (Depdiknas, 2008 : 11-12).

Lokasi penelitian adalah di SD Negeri 145 Palembang yang beralamat di Jl. Hokky Kampus No. 558 Kel. Lorok Pakjo Kec. Ilir Barat I Kota Palembang.Waktu pelaksanaan direncanakan selama dua bulan mulai dari September s.d Oktober 2018. Yang menjadi subyek dalam PTS ini adalah guru SD Negeri 145 Palembang dengan subjek penelitian sebanyak 8 orang.

Sumber data dalam PTS ini adalah aktivitas guru, silabus, dan rencana pelaksanaan pembelajaran (RPP) yang sudah dibuat guru. Peneliti mengharapkan secara rinci indikatorhasil pencapaianapabila silabus dan rencana pelaksanaan pembelajaran (RPP) yang disusun oleh guru kelas dan guru mata pelajaran minimal mencapai nilai kulaitatif $\mathrm{B}$ (Baik).

Analisa data yang digunakan dalam penelitian ini adalah analisa data kualitatif dan kuantitaif yang bersumber dari data primer maupun empiris. Melalui analisa data ini, dapat diketahui ada tidaknya peningkatan kompetensi guru dalam menyusun silabus dan RPP melalui bimbingan berkelanjutan yang merupakan fokus dari penelitian tindakan sekolah ini.

\section{PEMBAHASAN}

\section{SiklusI}

Siklus 1 terdiri atas beberapa tahap, yaitu : (1) Perencanaan, (2) Pelaksanaan, (3) obsevasi, dan (4) Refleksi.Peneliti melaksanakan rencana tindakan individual /kelompok untuk menilai administrasi guru yang sudah dikumpulkan sebelumnya. Pelaksanaan dilakukan dengan pertemuan individual officeconference. Hal ini dilakukan terutama kepada guru yang tidak mengumpulkan perangkat pembelajaran, untuk mengetahui penyebab/ masalahnya. Tahap ini peneliti rencanakan berlangsung selama dengan kolaborator.

Pada tahap ini peneliti melakukan kegiatan observasi terhadap seluruh kejadian yang terjadi selama tahap pelaksanaan dan mengobservasi hasil yang dicapai pada pelaksanaan tindakan siklus I. Selain itu peneliti juga mengidentifikasi masalah-masalah lanjutan yang timbul dari pelaksanaan tindakan di siklus I. 
Berdasarkan hasil observasi penelitian terhadap aktivitas guru khusunya aspek perilaku guru dimana pada siklus I kegiatan yang paling dominan adalah Pengendalian diri, pemanfaatanwaktu dengan rata-rata 91,875, nilai rata-rata aktivitas yang cukup besar yakni aspek perilaku Perilaku positif mebantu kelancaran pembelajaran 85,625 , memberi contoh yang dapat diteladani (tekun, jujur,konunikatif) 85. Sedangkan aspek perilaku mengajukan pertanyaan, bertanggung jawab dan membela kepetingan bersama masing-masing sebesar 70,625. Aspek perilaku yang menjadi perhatian untuk lebih ditingkatkan lagi adalah mampu membuat saran nyata menyangkut materi yang sedang dibahas dan menyampaikan gagasan/ide baru yang kritis dan konstruktif. Sedangkan hasil pengamatan serta rekap dari hasil penilaian penyusunan silabus dalam 2 kali tatap muka dapat dilihat pada tabel 1 sebagai berikut :

Tabel 1 Rekapitulasi Penilaian Silabus pada \begin{tabular}{|l|l|c|c|c|}
\multicolumn{5}{|c|}{ Siklus I } \\
\hline No & $\begin{array}{c}\text { Klasifikasi } \\
\text { Penilaian }\end{array}$ & $\begin{array}{c}\text { Rentan } \\
\text { gnilai }\end{array}$ & f & $\%$ \\
\hline A. & SILABUS & & & \\
\hline 1 & A : Baik & $80-$ & 2 & $25 \%$ \\
\hline
\end{tabular}

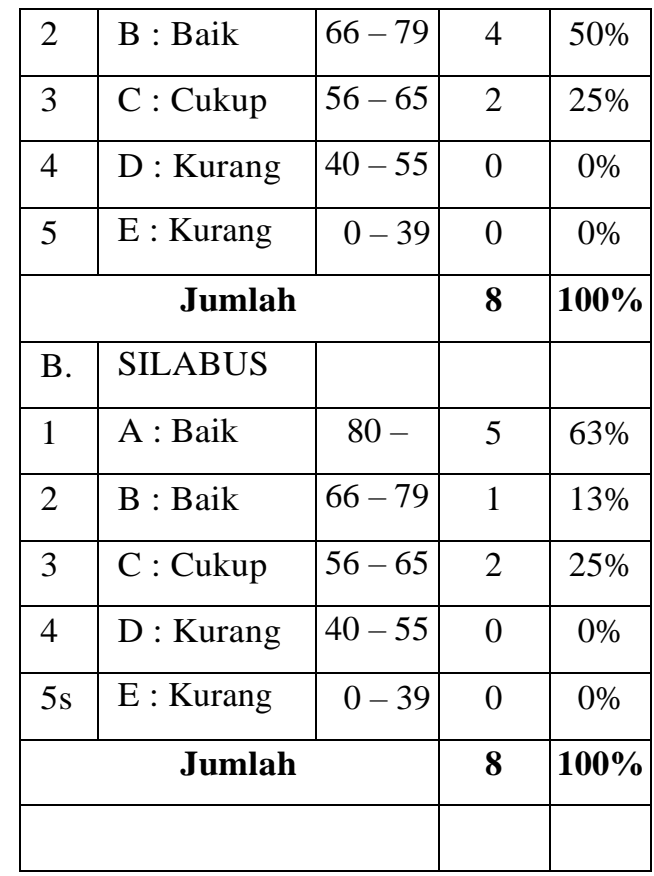

Pada table diatas hasil penilaian silabus pada tatap muka yang pertama terdapat 6 guru yang telah mencapai target, masih 2 guru yang belum mencapai indikator hasil pencapaian dimana apabila silabus yang disusun oleh guru kelas dan guru mata pelajaran minimal mencapai nilai kulaitatif B (Baik). Pada tabel memperlihatkan terjadinya peningkatan kompetensi guru dalam menyusun silabus dimana hasil penilaiannya yakni 5 guru yang kategori baik sekali sedangkan 1 orang guru yang kategorinya baik ini menunjukan bahwa telah tercapai indikator hasil pencapaian dimana apabila silabus yang disusun oleh guru kelas dan guru mata pelajaran 
minimal mencapai nilai kualitatif $\mathrm{B}$ (Baik).

Setelah selesai satu siklus maka diadakan refleksi mengenai kelemahan atau kekurangan dari pelaksanaan tindakan pada siklus pertama. Refleksi dilaksanakan bersama-sama kolaborator untuk menentukan tindakan perbaikan pada siklus berikutnya. Dari hasil refleksi dapat diambil suatu kesimpulan bahwa perlu penerapan bimbingan berkelanjutan aktivitas guru pada aspek perilaku yang menjadi perhatian untuk lebih ditingkatkan lagi adalah mampu membuat saran nyata menyangkut materi yang sedang dibahas dan menyampaikan gagasan/ide baru yang kritis dan konstruktif sehingga menjadi perhatian pada siklus berikutnya. Sedangkan hasil penilaian kompetensi guru dalam menyusun silabus telah berhasil dimana pada tatap muka ke 2 diperoleh semua guru telah mencapai nilai minimal kualitatif B (Baik).

\section{Siklus II}

Pada tahap ini, guru-guru yang sudah siap perangkat perencanaan pembelajarannya dikumpulkan untuk dinilai. Hal ini untuk melihat kesesuaian perencanaan pembelajaran dengan pelaksanaan pembelajaran.

Di tahap observasi siklus kedua, peneliti mengobservasi kesesuaian perencanaan pembelajaran dengan pelaksanaan pembelajaran serta melihat keberterimaan siswa dalam proses belajar mengajar. Pada tahap ini pula, peneliti mengumpulkan data-data yang terjadi selama tahap pelaksanaan. Berdasarkan hasil observasi penelitian terhadap aktivitas guru khusunya aspek perilaku guru dimana pada siklus I kegiatan yang paling dominan adalah Pengendalian diri, pemanfaatan waktu dengan rata-rata 95 , nilai rata-rata aktivitas yang cukup besar yakni perilaku positif mebantu kelancaran pembelajaran, mengajukan pertanyaan, bertanggung jawab masing-masing sebesar 90. Memberi contoh yang dapat diteladani (tekun, jujur, konunikatif) sebesar 89,375. Sedangkan aspek perilaku membela kepetingan bersama mengalami peningkatan sebesar 85. Aspek perilaku yang menjadi perhatian pada siklus I adalah sudah mengalami peningkatan lebih baik yakni aktivitas pada aspek perilaku mampu membuat saran nyata menyangkut materi yang 
sedang dibahas sebesar 73,125 dan penskoran, dan kunci jawaban menyampaikan gagasan/ide baru yang kemudian pedoman penskoran dan kritis dan konstruktif sebesar 82,5. kunci jawaban.Selanjutnya mereka Sedangkan hasil pengamatan serta dibimbing dan disarankan untuk rekap dari hasil penilaian penyusunan melengkapinya pada tatap muka II. RPP dalam 2 kali tatap muka pada Pada table memperlihatkan siklus II dapat dilihat pada tabel 2 terjadinya peningkatan kompetensi sebagai berikut :

Tabel 2 Rekapitulasi Penilaian RPP (Siklus II)

\begin{tabular}{|c|c|c|c|c|}
\hline \\
\hline No & $\begin{array}{r}\text { KlasifikasiP } \\
\text { enilaian }\end{array}$ & $\begin{array}{c}\text { Re } \\
\text { nta } \\
\text { ngn }\end{array}$ & $\mathbf{F}$ & $\%$ \\
\hline A. & RPP (Tatap & & & \\
\hline 1 & A : Baiksekali & $80-$ & 6 & $75 \%$ \\
\hline 2 & B : Baik & $66-79$ & 2 & $25 \%$ \\
\hline 3 & C : Cukup & $56-65$ & 0 & $0 \%$ \\
\hline 4 & D : Kurang & $40-55$ & 0 & $0 \%$ \\
\hline 5 & E : Kurang & $0-39$ & 0 & $0 \%$ \\
\hline \multicolumn{3}{|c|}{ Jumlah } & 15 & 100 \\
\hline No & $\begin{array}{r}\text { Klasifikasi } \\
\text { Penilaian }\end{array}$ & $\begin{array}{r}\text { Re } \\
\text { nta }\end{array}$ & $\mathbf{F}$ & $\%$ \\
\hline A. & RPP (Tatap & & & \\
\hline 1 & A : Baiksekali & $80-$ & 7 & $88 \%$ \\
\hline 2 & B : Baik & $66-79$ & 1 & $13 \%$ \\
\hline 3 & C : Cukup & $56-65$ & 0 & $0 \%$ \\
\hline 4 & D : Kurang & $40-55$ & 0 & $0 \%$ \\
\hline 5 & E : Kurang & $0-39$ & 0 & $0 \%$ \\
\hline \multicolumn{3}{|c|}{ Jumlah } & 8 & $100 \%$ \\
\hline
\end{tabular}

Pada tabel 2 hasil penilaian RPP pada tatap muka I terdapat 8 guru yang telah mencapai target, namun masih ada hal yang perlu diperbaiki pada kurangnya melengkapi RPP dengan soal, pedoman guru dalam menyusun RPP dimana hasil penilaiannya yakni 7 guru yang kategori baik sekali sedangkan 1 guru yang kategorinya baik ini menunjukan bahwa telah tercapai indikator hasil pencapaian dimana apabila RPP yang disusun oleh guru kelas dan guru mata pelajaran minimal mencapai nilai kualitatif B (Baik) dan guru hampir semuanya telah melengkapi komponen RPP yang belum lengkap pada tatap muka I.

Setelah selesai satu siklus maka diadakan refleksi mengenai kelemahan atau kekurangan dari pelaksanaan tindakan pada siklus II. Refleksi dilaksanakan bersama-sama kolaborator untuk menentukan tindakan perbaikan pada siklus berikutnya. Dari hasil refleksi siklus II dapat diambil suatu kesimpulan bahwa perlu penerapan bimbingan berkelanjutan aktivitas guru pada aspek perilaku yang menjadi perhatian untuk lebih ditingkatkan lagi adalah mampu 
membuat saran nyata menyangkut kompetensi guru dalam menyusun materi yang sedang dibahas dan silabus dan RPP.

menyampaikan gagasan/ide baru yang

Berdasarkan analisis data, kritis dan konstruktif sehingga menjadi diperoleh aktivitas guru dalam aspek perhatian pada siklus berikutnya.Aspek perilaku yang menjadi perhatian pada siklus I adalah sudah mengalami peningkatan lebih baik yakni aktivitas pada aspek perilaku mampu membuat saran nyata menyangkut materi yang sedang dibahas dan menyampaikan gagasan/ide baru yang kritis dan konstruktif. Sedangkan hasil penilaian kompetensi guru dalam menyusun RPP telah berhasil dimana pada tatap muka ke 2 diperoleh semua guru telah mencapai nilai minimal kualitatif $\mathrm{B}$ (Baik).

\section{Pembahasan}

Dari hasil wawancara terhadap lima belas orang guru, peneliti memperoleh informasi bahwa para guru sedikit sekali yang paham tentang menyusun silabus dan RPP sehingga untuk memperoleh dengan cara mengadopsi saja. Akan tetapi setiap guru setuju bahwa dalam proses belajar mengajar membutuhkan silabus dan RPP untuk bahan acuan dalam proses belajar mengajar maka dari itu peneliti memfokuskan untuk meningkatkan perilaku dengan bimbingan berkelanjutan yang paling dominan adalah pengendalian diri, pemanfaatan waktu. Jadi dapat dikatakan bahwa aktivitas guru dapat dikategorikan aktif, nilai rata-rata aktivitas yang cukup besar yakni aspek perilaku Perilaku positif mebantuk kelancaran pembelajaran dan memberi contoh yang dapat diteladani (tekun, jujur,konunikatif). Dari siklus I sampai siklus II aktivitas guru mengalami peningkatan. Hal ini terlihat pada grafik 1 sebagai berikut :

Grafik 1 Aktivitas Guru

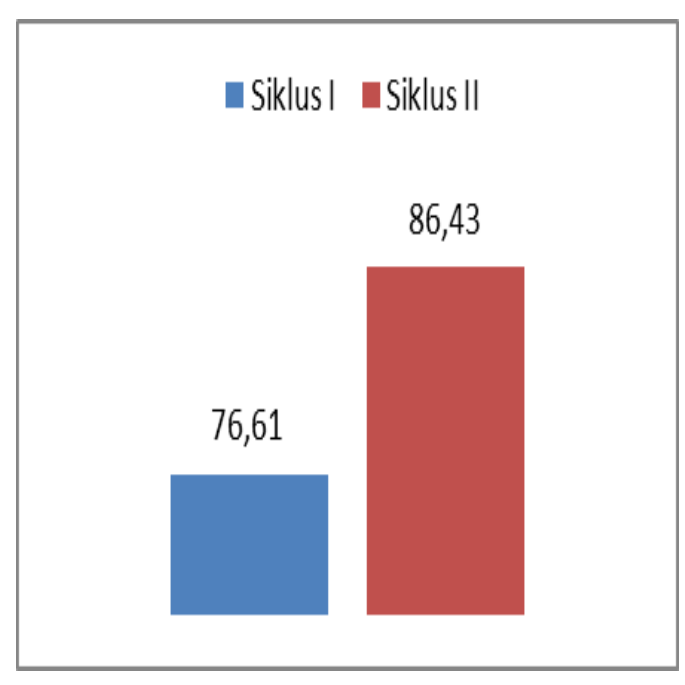

Melalui hasil penelitian ini menunjukkan bahwa penerapan bimbingan berkelanjutan memiliki 
dampak positif dalam meningkatkan kompetensi guru dalam menyusun silabus dan RPP. Hal ini dapat dilihat dari semakin mantapnya kompetensi guru dalam menyusun silabus dan RPP (ketuntasan kompetensi meningkat dari siklus I dan II) yaitu masing-masing 74 dan 80,5. Hubungan aktivitas guru dengan kompetensi guru dalam menyusun silabus dan RPP saling terkait meningkatnya hasil aktivitas guru berdampak pada kompetensi guru dimana adanya peningkatan pada tiap tatap muka. Hal ini dapa dilihat pada data di bawah.

Garfik 2 Pencapaian Kompetensi

Guru

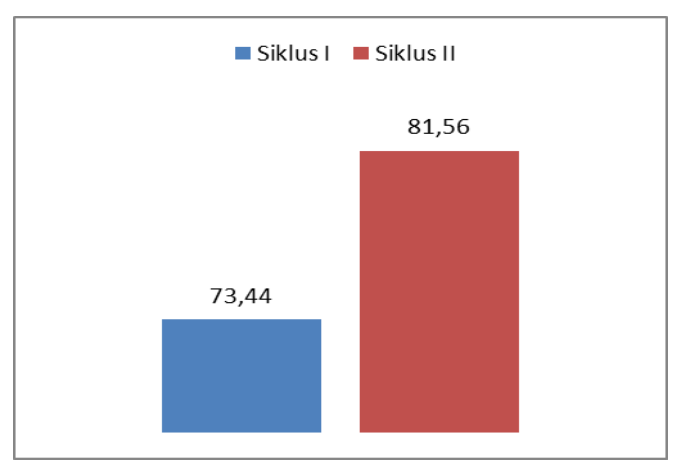

\section{KESIMPULAN}

Berdasarkan analisis data, dari penelitian ini dapat ditarik kesimpulan bahwa penerapan bimbingan berkelanjutan efektif untuk meningkatkan kompetensi guru dalam menyusun perangkat kurikulum.
Data yang diperoleh menunjukan bahwa setelah diadakan penerapan tindakan penerapan bimbingan berkelanjutan yakni pada siklus I rata-rata hasil aktivitas dan kompetensi guru dalam menyusun silabus dan RPP adalah 75,91 dan pada siklus II rata-rata hasil aktivitas dan kompetensi guru dalam menyusun silabus dan RPP mengalami peningkatan yakni sebesar 85,35. Hal ini berarti penelitian telah berhasil dimana apabila silabus dan RPP yang disusun oleh guru kelas dan guru mata pelajaran minimal mencapai nilai kualitatif B (Baik)

Adanya pengaruh positif Penerapan bimbingan berkelanjutan terhadap bagaimana cara menyusun silabus dan RPP, maka melalui kesempatan ini penulis mengajukan beberapasaran : Dalam upaya meningkatkan kompetensi guru dalam menyusun silabus dan RPP, maka salah satu bentuk kegiatan untuk dapat dilakukan oleh satuan pendidikan adalah melakukan bimbingan berkelanjutan. Agar kegiatan bimbingan berkelanjutan dapat dilaksanakan secara optimal, maka perlu sekolah mengalokasikan dana kegiatan secara memadai. 


\section{DAFTAR PUSTAKA}

Depdiknas. 2004. Standar Kompetensi Guru Sekolah Dasar. Jakarta: Depdiknas.

Depdiknas. 2008. Alat Penilaian Kemampuan Guru. Jakarta: Depdiknas.

Kurniawati, E. D. 2009. Tesis: Pengembangan Bahan Ajar Bahasa dan Sastra Indonesia dengan Pendekatan Tematis (Studi Pengembangan di SMA Negeri 2 Sambas). Program Pascasarjana Universitas Sebelas Maret Surakarta. [Online]. http://core.ac.uk/download/pdf /16507546.pdf. [Diakses 15 Agustus 2019].

Nurhadi. 2004. Kurikulum 2013 Jakarta: PT Gramedia Widiasarana Indonesia.

Sudjana, Nana. 2009. Standar Kompetensi Kepala Sekolah Dimensi dan Indikator. Jakarta : Binamitra Publishing.

Suparlan. 2005. : Menjadi Guru Efektif. YogyakartaHikayat Publishing. 